\title{
Kompetensi Sumber Daya Manusia dan Impementasi Sistem Keuangan Desa dan Akuntabilitas Pengelolaan Dana Desa
}

\author{
Putu Ayu Ratih Ardianti ${ }^{1}$ \\ Fakultas Ekonomi dan Bisnis \\ Universitas Udayana, Indonesia
}

\author{
I Wayan Suartana ${ }^{2}$ \\ Fakultas Ekonomi dan Bisnis \\ Universitas Udayana, Indonesia
}

\begin{abstract}
Surel : ptayuratih@gmail.com
\section{ABSTRAK}

Tujuan penelitian ini adalah untuk mengetahui pengaruh kompetensi sumber daya manusia dan sistem keuangan desa terhadap akuntabilitas pengelolaan dana desa di Kabupaten Badung. Penelitian ini dilakukan pada desa- desa yang terdapat di Kabupaten Badung dengan menggunakan sampel sebanyak 126 responden yang terdiri dari Kepala Desa, Sekretaris Desa, Bendahara serta Kepala Seksi, dengan teknik probability sampling dengan metode proportionate stratified random sampling. Pengumpulan data dilakukan melalui penyebaran kuesioner. Teknik analisis yang digunakan pada penelitian ini adalah analisis regresi linier berganda. Hasil penelitian ini menunjukkan bahwa kompetensi sumber daya manusia berpengaruh positif pada akuntabilitas pengelolaan dana desa. Sistem keuangan desa berpengaruh positif dan signifikan pada akuntabilitas pengelolaan dana desa.
\end{abstract}

Kata Kunci: Kompetensi; Sistem Keuangan Desa; Akuntabilitas.

\section{Human Resource Competence and Village Financial System Implementation and Village Fund Management Accountability}

\begin{abstract}
The purpose of this study was to determine the effect of human resource competencies and village financial systems on the accountability of village fund management in Badung Regency. This research was conducted in villages in Badung Regency using a sample of 126 respondents consisting of Village Heads, Village Secretaries, Treasurers and Section Heads, with probability sampling technique with proportionate stratified random sampling method. Data collection was carried out through questionnaires. The analysis technique used in this study is multiple linear regression analysis. The results of this study indicate that human resource competence has a positive effect on village fund management accountability. The village financial system has a positive and significant effect on the accountability of village fund management.
\end{abstract}

Keywords: Competence; Village Financial System; Accountability.

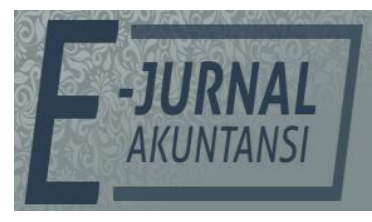

e-ISSN 2302-8556

Vol. 30 No. 11

Denpasar, Nopember 2020

Hal. 2839-2851

DOI:

10.24843/EJA.2020.v30.i11.p10

PENGUTIPAN:

Ardianti, P.A.R. \& Suartana,

I W. (2020). Kompetensi

Sumber Daya Manusia dan Impementasi Sistem Keuangan Desa dan Akuntabilitas Pengelolaan Dana Desa. E-Jurnal Akuntansi, 30(11), 2839-2851

RIWAYAT ARTIKEL:

Artikel Masuk:

25 Desember 2019

Artikel Diterima:

21 Februari 2020

Artikel dapat diakses : https://ojs.unud.ac.id/index.php/Akuntansi/index 


\section{PENDAHULUAN}

Dana desa adalah dana APBN yang diperuntukkan bagi desa yang ditransfer melalui APBD Kabupaten/ Kota dan diprioritaskan untuk pelaksanaan pembangunan dan pemberdayaan masyarakat. Tujuan dari pemberian dana ini adalah untuk meningkatkan pelayanan publik desa, menuntaskan kemiskinan, memajukan perekonomian desa, mengatasi kesenjangan pembangunan antar desa. Tahun 2015 merupakan awal dari pemberian dana desa yang jumlahnya sebesar Rp 20 Triliun. Tahun 2018 dana sebesar Rp 60 triliun dan ditahun 2019 ini dana desa meningkat menjadi Rp 70 triliun dilansir dari Direktorat Jenderal Perimbangan Keuangan. Pelaksanaan APBDes memiliki peran penting dalam mensukseskan pembagunan daerah dan menjadi cerminan kinerja dan kemampuan pemerintah desa dalam membiayai dan mengelola penyelenggaraan pemerintah dan pelaksanaan pembangunan di desa. Pengelolaan keuangan dana desa menjadi kunci utama keberhasilan otonomi desa (Gayatri, et al., 2017).

Besarnya dana yang dikucurkan pemerintah pusat untuk desa menjadikan dana ini rentan terhadap penyelewengan/ korupsi. Berkaitan dengan kebijakan dana desa, Badan Pemeriksa Keuangan menyebutkan adanya permasalahan dalam pengelolaan keuangan desa yang bersumber dari minimnya pengetahuan perangkat desa dalam tata kelola dan pelaporan keuangan sehingga berpotensi terjadi penyelewengan atau korupsi (Abidin, 2015). Dana desa ini diberikan keseluruh provinsi yang berada di Indonesia termasuk Bali.

Bali salah satu provinsi yang menerima kucuran dana desa. Pengalokasian dana desa untuk Provinsi Bali dibagikan kepada 8 kabupaten dan 1 kota madya. Jumlah seluruh desa yang berada di Bali sebanyak 636. Rincian dari dana desa untuk Provinsi Bali tahun 2019 dapat dilihat pada Tabel 1.

\section{Tabel 1. Daftar Rincian Dana Desa untuk Provinsi Bali Tahun 2019}

\begin{tabular}{llll}
\hline No & $\begin{array}{l}\text { Nama } \\
\text { Kabupaten/Kota }\end{array}$ & Jumlah Desa & $\begin{array}{l}\text { Total Dana Desa } \\
(\mathrm{Rp})\end{array}$ \\
\hline 1 & Badung & 46 & 52.584 .767 \\
2 & Bangli & 68 & 61.334 .645 \\
3 & Buleleng & 129 & 124.026 .738 \\
4 & Gianyar & 64 & 59.992 .299 \\
5 & Jembrana & 41 & 49.043 .178 \\
6 & Karangasem & 75 & 78.718 .974 \\
7 & Klungkung & 53 & 51.533 .982 \\
8 & Tabanan & 133 & 118.204 .542 \\
9 & Denpasar & 27 & 34.750 .461 \\
Jumlah & & 676 & 630.144 .761 \\
\hline
\end{tabular}

Sumber: Data Penelitian, 2019

Rincian dana desa untuk Provinsi Bali pada tahun 2019 dapat kita ketahui bahwa Kabupaten Badung dengan total desa yang berjumlah 46 mendapatkan dana sejumlah Rp 52.584.767.000,- dengan urutan ketiga yang mendapat dana terkecil. Badung merupakan kabupaten dengan tingkatan realisasi PAD tertinggi di Bali dengan jumlah Rp 4,17 triliun (www.kabar24.bisnis.com), hal itu disebabkan sektor pariwisatanya yang dapat dikatakan sudah dikelola dengan baik. Badung sebenarnya memiliki 6 kecamatan namun hanya 5 kecamatan yang 
terdiri dari 46 desa dan 1 kecamatan terdiri atas kelurahan. Artikel nusabali.com menyatakan dengan realisasi sebesar itu Badung mampu menggelontorkan dana besar untuk anggaran dana desa. Pada tahun 2019 ini Badung mengalokasikan dana desa sebesar Rp 675 milyar yang akan diberikan untuk 46 desa. Adapun rincian dana desa untuk Kabupaten Badung tahun 2019 dapat dilihat pada Tabel 2.

Tabel 2. Daftar Rincian Dana Desa untuk Kabupaten Badung Tahun 2019

\begin{tabular}{|c|c|c|c|c|c|c|c|}
\hline No & $\begin{array}{l}\text { Nama } \\
\text { Kecamat } \\
\text { an }\end{array}$ & $\begin{array}{l}\text { Jml } \\
\text { Des } \\
\text { a }\end{array}$ & $\begin{array}{l}\text { Bagi Hasil } \\
\text { Pajak } \\
\text { Daerah } \\
(\mathrm{Rp})\end{array}$ & $\begin{array}{l}\text { Bagi } \\
\text { Hasil } \\
\text { Retribusi } \\
\text { Daerah } \\
(\mathrm{Rp})\end{array}$ & $\begin{array}{l}\text { Dana } \\
\text { Perimban } \\
\text { gan } \\
(\mathrm{Rp})\end{array}$ & $\begin{array}{l}\text { Dana Desa } \\
(\mathrm{Rp})\end{array}$ & $\begin{array}{l}\text { Total } \\
\text { Terima } \\
\text { Dana ke } \\
\text { Desa } \\
(\mathrm{Rp})\end{array}$ \\
\hline 1 & & 15 & & 5.248 .892 & & & $\begin{array}{l}210.803 .76 \\
5\end{array}$ \\
\hline 2 & $\begin{array}{l}\text { Abiar } \\
\text { mal }\end{array}$ & 18 & $\begin{array}{l}210.004 .81 \\
5\end{array}$ & 6.279 .698 & & 20.372 .165 & $\begin{array}{l}253.369 .29 \\
2\end{array}$ \\
\hline 3 & Petang & 7 & 92.473 .959 & 2.765 .215 & 7.359 .267 & 9.912 .147 & $\begin{array}{l}112.510 .58 \\
8\end{array}$ \\
\hline 4 & $\begin{array}{l}\text { Kuta } \\
\text { Selatan }\end{array}$ & 3 & 40.054 .207 & 1.197.726 & 3.187.595 & 3.210 .575 & 47.650.105 \\
\hline 5 & $\begin{array}{l}\text { Kuta } \\
\text { Utara }\end{array}$ & 3 & 43.124 .706 & 1.289 .542 & 3.431 .952 & 3.034.787 & 50.880 .988 \\
\hline Total & & 46 & $\begin{array}{l}561.188 .43 \\
1\end{array}$ & $\begin{array}{l}16.781 .01 \\
5\end{array}$ & 44.660 .525 & $\begin{array}{l}52.584 .76 \\
7 \\
\end{array}$ & $\begin{array}{l}675.214 .73 \\
9 \\
\end{array}$ \\
\hline
\end{tabular}

Sumber: Dinas Pemberdayaan Masyarakat dan Desa Kabupaten Badung, 2019

Pada tabel terlihat dana desa terbesar diberikan pada kecamatan Abiansemal dengan jumlah desa terbanyak dilanjutkan dengan kecamatan Mengwi, Petang, Kuta Utara dan Kuta Selatan yang terkecil. Nominal dana yang diberikan oleh pemerintah daerah Badung kepada kecamatan- kecamatan yang berada di Badung tersebut terbilang besar untuk itu diharapkan dapat dipergunakan sebaik mungkin untuk meningkatkan taraf hidup masyarakatnya. Besarnya pendapatan yang diterima desa menimbulkan kekhawatiran terkait kesiapan desa dalam mengelola dana desa secara bertanggung jawab.

Terbukti dengan adanya kasus korupsi dana desa di tahun 2018 yang dilakukan oleh kepala desa Baha sebanyak Rp 1 milyar yang menyebabkan beberapa kegiatan seperti pembangunan Balai Subak Lepud, pengadaan perlengkapan Museum Subak Lepud, pembelian mobil operasional kantor, penyuluhan hukum LPM serta kegiatan penanaman pohon kamboja dan baru divonis 4,5 tahun penjara di tahun 2019 ini yang dilansir dari (www.bali.tribunnews.com, 2019) dan kasus korupsi yang dilakukan oleh Bendahara Desa yang dibantu oleh Staf pembantu kepala urusan keuangan dan Perbekel dituding melakukan pembiaran pada bawahannya dan ceroboh menandatangani formulir kosong di Mengwitani. Perangkat desa tersebut terbukti bersalah melakukan penggelapan APBDes dalam pengelolaan keuangan Desa Mengwitani yang merugikan keuangan negara sebesar Rp 1,2 miliar lebih dan terdakwa divonis 2,5 tahun penjara dan membayar uang pengganti sebesar Rp 300 juta (www.baliexpress.jawapos.com, 2018). Maka dari itu penting untuk 
mewujudkan akuntabilitas dalam pengelolaan dana desa untuk menumbuhkan kepercayaan publik terhadap kinerja keuangan pemerintah.

Akuntabilitas bukan sekedar pertanggungjawaban keuangan secara formal kepada prinsipal, tetapi pertanggungjawaban yang meliputi kepatuhan pada peraturan, lingkungan organisasi, masyarakat dan pemerintah (Mahayani, 2017). Tuntutan mengenai akuntabilitas pengelolaan dana desa menjadi fokus penting bagi perangkat desa karena akuntabilitas tersebut menunjukkan keberhasilan tercapainya visi dari UU Desa untuk mewujudkan desa yang maju, kuat, mandiri, demokratis dan berkeadilan untuk mencapai kesejahteraan masyarakat desa. Pertanggungjawaban perangkat desa disajikan dalam bentuk laporan keuangan yang dihasilkan melalui proses akuntansi yang transparan dan akuntabel pengelolaan dana desa.

Tuntutan atas akuntabilitas pengelolaan keuangan semakin tinggi tetapi hasil penelitian menunjukkan bahwa banyak organisasi pemerintah tidak mampu mewujudkan akuntabilitas pengelolaan keuangan pemerintah dengan baik (Gayatri, et al., 2017). Pemerintah sebagai pengelola keuangan memiliki kewajiban untuk menyampaikan informasi keuangan dan informasi lainnya yang dapat digunakan untuk pengambilan keputusan ekonomi dan sosial secara transparan dan akuntabel. Pengelolaan dana desa yang baik diperlukan aparat pemerintah yang memiliki kemampuan serta bertanggungjawab mengelola dana tersebut (Fajri, et al., 2015).

Kompetensi sumber daya manusia (SDM) sebagai faktor penentu organisasi atau lembaga pemerintahan, maka dari itu kompetensi sumber daya manusia menjadi aspek yang menentukan keberhasilan organisasi atau lembaga pemerintahan. Kompetensi jajaran perangkat desa sangat penting dalam kaitannya dengan pengelolaan dana desa yang nantinya berpengaruh pada pembangunan desa. Faktor yang menjadi penghambat pengelolaan keuangan desa adalah terbatasnya kemampuan aparatur pemerintahan desa dan lemahnya kinerja pengelolaan (Diansari, 2015). Penelitian Gayatri, et al., (2019) menyimpulkan bahwa kompetensi sumber daya manusia berpengaruh terhadap akuntabilitas keuangan daerah. Hal sejalan dengan penelitian Indrajaya (2017) yang menyatakan bahwa kompetensi berpengaruh positif terhadap akuntabilitas dana desa.

Penggunaan teknologi informasi dalam suatu organisasi desa dalam melaksanakan pengelolaan dana desa dapat membantu untuk mengatasi penyelewengan dana. Tujuan dari penerapan teknologi informasi adalah efisien tinggi dan responsif dalam pelayanan publik Hertati (2015). Romney \& Steinbart (2015) menyatakan bahwa sistem informasi akuntansi merupakan suatu sistem yang mengumpulkan, mencatat, menyimpan, dan mengolah data untuk menghasilkan informasi bagi pengambilan keputusan. Pentingnya penggunaan sistem informasi dalam menghasilkan informasi yang berkualitas dan mendukung proses pengambilan keputusan dapat meningkatkan efisiensi organisasi (Nabizadeh, 2014).

Implementasi teknologi baru dalam suatu organisasi tidak mudah, terutama ketika itu terkait dengan bagaimana pengguna menerima teknologi yang akan diadopsi. Ini karena penerapan teknologi baru akan mempengaruhi seluruh organisasi, terutama sumber daya manusia (Widagdo \& Setyorini, 2018). 
Sistem akuntansi yang dirancang dan dijalankan dengan baik akan menjamin akuntabilitas dengan baik. Sistem informasi yang dikembangkan dalam organisasi dan lembaga- lembaga pada dasarnya memiliki tujuan untuk mengolah informasi secara cepat dan akurat (Indralesmana \& Suaryana, 2014). Hal ini tercermin dengan penerapan sistem informasi keuangan desa atau yang lebih dikenal dengan SISKEUDES. Penelitian Achyani (2019) menyatakan bahwa sistem keuangan desa berpengaruh terhadap akuntabilitas pengelolaan dana desa dan sejalan dengan penelitian Julianto (2019) menyatakan sistem keuangan desa berpengaruh positif terhadap keberhasilan pengelolaan dana desa.

Aplikasi Sistem Keuangan Desa (SISKEUDES) merupakan gebrakan dari Pemerintah Pusat (Kemendagri) bekerjasama dengan Badan Pengawas Keuangan Pembangunan (BPKP) untuk lebih memudahkan menata pelaporan pengelolaan dana desa. Penerapan sistem ini juga ditenggarai penyelewengan dana desa masih terjadi di Indonesia termasuk di Bali. Penggunaan SISKEUDES juga dipertegas dengan himbauan Komisi Pemberantasan Korupsi (KPK) melalui surat Nomor B. 7508/01-16/08/2016 tertanggal 31 Agustus 2016 kepada seluruh kepala desa di Indonesia untuk memahami dengan baik dan menggunakan SISKEUDES dalam pengelolaan dana desa. SISKEUDES akan menghasilkan output RPJM (Rencana Pembangunan Jangka Menengah) dan RKP (Rencana Kerja Pemerintah) Desa, APB (Anggaran Pendapatan dan Belanja) Desa, dokumen penatausahaan keuangan desa, laporan realisasi per sumber dana.

Pemerintahan Kabupaten Badung telah melakukan kerjasama dengan Badan Pengawas Keuangan Pembangunan (BPKP) Perwakilan Bali dengan menandatangani MoU tanggal 4 Maret 2016 untuk penerapan penggunaan SISKEUDES dalam pengelolaan dana desa. Pemerintah Kabupaten Badung menerapkan sistem ini karena jumlah dana desa yang dikucurkan terbilang sangat besar terlansir dari bali.antaranews.com (2016) dan dapat memicu terjadinya tindak korupsi jika tidak dikelola dengan baik. Teori yang digunakan dalam penelitian ini adalah Stewardship theory. Stewardship theory adalah teori yang menggambarkan situasi dimana para manajer tidaklah termotivasi oleh tujuan- tujuan individu tetapi lebih ditujukan pada sasaran hasil utama mereka untuk kepentingan organisasi, sehingga para eksekutif sebagai steward termotivasi untuk bertindak sesuai keinginan principal, selain itu perilaku steward tidak akan meninggalkan organisasinya sebab steward berusaha mencapai sasaran organisasinya. Teori ini didesain bagi para peneliti untuk menguji situasi dimana para eksekutif dalam perusahaan sebagai steward dapat termotivasi untuk bertindak dengan cara terbaik pada principal nya (Donaldson \& Davis, 1991).

Kompetensi sumber daya manusia mencakup kapasitas terkait kemampuan seseorang atau organisasi untuk mencapai tujuannya. Oleh karena itu dalam sebuah organisasi agar tercapai suatu tujuan harus memiliki sumber daya manusia yang kompeten. Dalam pengelolaan dana desa, pemerintah desa yaiu aparatur desa harus memiliki kompetensi sumber daya manusia yang berkualitas yang dapat dilihat dari latar belakang pendidikan, pengalaman mengikuti pelatihan, mengerti tentang akuntansi dan dana desa serta memahami peraturan dan prosedur mengenai pengelolaan dana desa beserta tujuan dana 
tersebut diberikan oleh pemerintah. Kompetensi aparatur desa yang baik sudah pasti akan mendukung akuntabilitas pengelolaan dana desa.

Penelitian yang dilakukan oleh Gayatri, et al., (2019) dan Makalag (2017) menyatakan bahwa kompetensi aparatur desa berpengaruh positif terhadap akuntabilitas pengelolaan dana desa. Penelitian tersebut berbeda dari penelitian yang dilakukan oleh Diarespati, et al., (2017) yang menyatakan bahwa kompetensi aparatur desa tidak berpengaruh signifikan terhadap akuntabilitas pengelolaan dana desa.

$\mathrm{H}_{1}$ : Kompetensi Sumber Daya Manusia berpengaruh positif terhadap Akuntabilitas Pengelolaan Dana Desa.

Pemanfaatan teknologi informasi dalam suatu organisasi desa akan membantu desa dalam melaksanakan tata kelola keuangan desa secara efisien. Berdasarkan stewardship theory, principals yaitu pemerintah pusat dan masyarakat berhak meminta pertanggungjawaban atas pengelolaan dana desa dari pemerintah desa (steward). Oleh karena itu pemerintah desa memiliki kewajiban membuat laporan sesuai dengan peraturan serta tidak mengandung unsur membingungkan bagi para pemakai laporan tersebut. SISKEUDES ini merupakan salah satu teknologi informasi yang disiapkan oleh Kemendagri bersama BPKP yang diharapkan bisa memperoleh kemudahan dan kesederhanaan dalam pengelolaan dana desa. Laporan yang dihasilkan oleh sistem keuangan desa ini nantikan akan digunakan oleh pemerinah pusat sebagai bahan evaluasi. Hariani (2013) menyatakan penggunaan sistem informasi yang kurang efektif akan berdampak negatif pada kinerja dan mutu pelayanan organisasi sektor publik pada masyarakat. Penelitian yang dilakukan oleh Abdullah \& Samad (2019) menyatakan bahwa sistem keuangan desa belum berpengaruh positif terhadap penyelenggaraan pemerintahan di Desa Tokaka namun berbeda dengan Penelitian Gayatri \& Latrini (2018) menyatakan bahwa penerapan SISKEUDES efektif terhadap kualitas laporan keuangan dana desa dan penelitian Sulina, et al., (2017) juga menyatakan bahwa SISKEUDES berpengaruh positif terhadap kinerja pemerintah desa di Desa Kaba- Kaba serta penelitian Jannah, et al., (2018) juga menyatakan bahwa penggunaan teknologi informasi berpengaru positif terhadap transparansi dan akuntabilitas pengelolaan dana desa.

$\mathrm{H}_{2}$ : Sistem Keuangan Desa berpengaruh positif terhadap Akuntabilitas Pengelolaan Dana Desa.

\section{METODE PENELITIAN}

Penelitian ini dilakukan di desa- desa yang tercatat secara administratif menerima dana desa di masing- masing kecamatan yang ada di Kabupaten Badung. Peneliti tertarik menggunakan desa- desa di Kabupaten Badung sebagai lokasi penelitian karena kasus penyelewengan terkait dana desa benar terjadi sehingga peneliti ingin mengetahui kompetensi sumber daya manusia dan implementasi sistem keuangan desa berpengaruh pada akuntabilitas dalam pengelolaan dana desa.

Populasi dalam penelitian ini adalah Perangkat Desa yang ketentutannya diatur dalam Peraturan Daerah Kabupaten Badung No. 8 Tahun 2015 yaitu perangkat desa yang terdiri dari Perbekel (Kepala Desa), Sekretaris Desa, 
Bendahara Desa, Kepala Seksi yang berada di 46 desa se- Kabupaten Badung. Untuk Kepala Seksi yang dijadikan responden adalah Kepala Seksi Kesejahteraan karena program kerjanya didanai oleh dana desa. Pengambilan sampel dalam penelitian ini dengan teknik probability sampling dengan proportionate stratified random sampling dengan menggunakan rumus Slovin. Dalam penelitian ini penulis mempersempit populasi yaitu jumlah Perangkat Desa sebanyak 184 responden dengan menghitung ukuran sampel yang dilakukan dengan teknik Slovin karena dalam penarikan sampel, jumlahnya harus representative agar hasil penelitian dapat digeneralisasikan.

Dalam menguji hipotesis dalam penelitian ini menggunakan analisis regresi linier berganda. Metode ini merupakan teknik analisis yang digunakan untuk menanggapi pengaruh dua atau lebih variabel bebas terhadap suatu variabel terikat. Adapun persamaan regresi linier berganda dalam penelitian ini adalah.:

$$
Y=\alpha+\beta_{1} X_{1}+\beta_{2} X_{2}+\varepsilon
$$

Keterangan:

$$
\begin{array}{ll}
\mathrm{Y} & =\text { Akuntabilitas Pengelolaan Dana Desa } \\
\mathrm{a} & =\text { Konstanta } \\
\mathrm{X}_{1} & =\text { Kompetensi } \\
\mathrm{X}_{2} & =\text { Sistem Keuangan Desa } \\
\mathrm{B}_{1} \beta_{2} & =\text { Koefisien Regresi } \\
\varepsilon & =\text { Error }
\end{array}
$$

\section{HASIL DAN PEMBAHASAN}

\begin{tabular}{|c|c|c|c|c|c|}
\hline Variabel & $\mathrm{N}$ & Minimum & Maximum & Mean & Std. Deviation \\
\hline Kompetensi & 126 & 11,99 & 29,41 & 23,23 & 4,81 \\
\hline $\begin{array}{l}\text { Implementasi Sistem } \\
\text { Keuangan Desa }\end{array}$ & 126 & 7,66 & 20,42 & 16,06 & 3,23 \\
\hline $\begin{array}{l}\text { Akuntabilitas Pengelolaan } \\
\text { Dana Desa }\end{array}$ & 126 & 18,53 & 37,82 & 30,32 & 5,92 \\
\hline
\end{tabular}

Pengujian Statistik Deskriptif digunakan untuk memberikan gambaran atau deskriptif suatu data yang dilihat dari nilai rata-rata (mean), nilai minimum, nilai maksimum, dan nilai dari data penelitian. Hasil dari pengujian statistik deskriptif dari masing-masing variabel penelitian disajikan pada Tabel 3. sebagai berikut:

Tabel 3. Hasil Uji Statistik Deskriptif

Sumber: Data Penelitian, 2019

Variabel kompetensi sumber daya manusia menggunakan indikator kemampuan, pelatihan, keterampilan, dan kerja sama yang berjumlah 8 item. Variabel kompetensi sumber daya manusia memiliki nilai minimum sebesar 11,99 dan nilai maksimum sebesar 29,41 dengan nilai rata-rata sebesar 23,23. Nilai standar deviasi variabel kompetensi sumber daya manusia sebesar 4,81 , menurut penjabaran dari hasil uji statistik deskriptif untuk variabel X1 disimpulkan dari 126 responden sebagian besar menyetujui pernyataanpernyataan yang diajukan dalam kuesioner.

Variabel implementasi sistem keuangan desa menggunakan indikator keamanan data, ketepatan waktu, ketelitian, relevansi, dan variasi laporan yang 
berjumlah 5 item. Variabel implementasi sistem keuangan desa memiliki nilai minimum sebesar 7,66 dan nilai maksimum sebesar 20,42 dengan nilai rata-rata sebesar 16,06 . Nilai standar deviasi variabel implementasi sistem keuangan desa sebesar 3,23, menurut penjabaran dari hasil uji statistik deskriptif untuk variabel X2 disimpulkan dari 126 responden sebagian besar menyetujui pernyataanpernyataan yang diajukan dalam kuesioner.

Variabel akuntabilitas pengelolaan dana desa menggunakan indikator perumusan rencana keuangan, transparansi, pembiayaan kegiatan, pertanggungjawaban dan evaluasi atas kinerja keuangan yang berjumlah 10 item. Variabel akuntabilitas pengelolaan dana desa memiliki nilai minimum sebesar 18,53 dan nilai maksimum sebesar 37,82. dengan nilai rata-rata sebesar 30,32. Nilai standar deviasi variabel transparansi sebesar 5,92, menurut penjabaran dari hasil uji statistik deskriptif untuk variabel Y disimpulkan dari 126 responden sebagian besar menyetujui pernyataan-pernyataan yang diajukan dalam kuesioner.

Model analisis regresi linear berganda digunakan untuk mendapat koefisien regresi yang akan menentukan apakah hipotesis yang dibuat akan diterima atau ditolak. Hasil analisis ini mengacu pada hasil pengaruh variabel Kompetensi Sumber Daya Manusia $\left(X_{1}\right)$, variabel Sistem Keuangan Desa $\left(X_{2}\right)$ terhadap Akuntabilitas Pengelolaan Dana Desa (Y) Di Kabupaten Badung. Adapun hasil analisis regresi dengan program Statitical Pacage of Social Science (SPSS) versi 21.0 for Windows dapat dilihat pada Tabel 4. berikut.

Tabel 4. Hasil Analisis Regresi Linear Berganda

\begin{tabular}{llllll}
\hline \multirow{2}{*}{ Model } & \multicolumn{2}{l}{$\begin{array}{l}\text { Unstandardized } \\
\text { Coefficients }\end{array}$} & $\begin{array}{l}\text { Standardized } \\
\text { Coefficients }\end{array}$ & $\mathrm{t}$ & Sig. \\
\cline { 2 - 5 } & $\mathrm{B}$ & Std. Error & Beta & & \\
\hline (Constant) & 4,072 & 1,718 & & 2,370 & 0,019 \\
$\begin{array}{l}\text { Kompetensi Sumber } \\
\text { Daya Manusia }\end{array}$ & 0,509 & 0,083 & 0,413 & 6,162 & 0,000 \\
Sistem Keuangan Desa & 0,897 & 0,123 & 0,489 & 7,287 & 0,000 \\
\hline
\end{tabular}

Sumber: Data Penelitian, 2019

Berdasarkan Tabel 5, dapat ditulis persamaan regresi linear berganda sebagai berikut:

Keterangan :

$$
Y=4,072+0,509 X_{1}+0,897 X_{2}
$$

$\mathrm{Y}=$ Akuntabilitas Pengelolaan Dana Desa

$\mathrm{X}_{1}=$ Kompetensi Sumber Daya Manusia

$\mathrm{X}_{2}=$ Implementasi Sistem keuangan desa

Nilai konstanta (a) menunjukkan besarnya nilai variabel dependen apabila variabel independen adalah 0 (nol). Nilai konstanta sebesar 4,072 menunjukkan besarnya akuntabilitas pengelolaan dana desa adalah sebesar 4,072 apabila kompetensi sumber daya manusia dan implementasi sistem keuangan desa adalah 0 (nol) dengan nilai signifikansi <0,05.

Nilai koefisien kompetensi sumber daya manusia $\left(X_{1}\right)$ 0,509 menunjukkan kompetensi sumber daya manusia bertambah sebesar 1 satuan maka nilai dari 
akuntabilitas pengelolaan dana desa $(\mathrm{Y})$ akan mengalami kenaikan sebesar 0,509 satuan dengan asumsi variabel bebas lainnya konstan.

Nilai koefisien implementasi sistem keuangan desa $\left(X_{2}\right)$ 0,897 menunjukkan implementasi sistem keuangan desa $\left(X_{2}\right)$ bertambah sebesar 1 satuan maka nilai dari akuntabilitas pengelolaan dana desa $(\mathrm{Y})$ akan mengalami kenaikan sebesar 0,897 satuan dengan asumsi variabel bebas lainnya konstan.

Analisis determinasi dilakukan untuk mengetahui sejauh mana variasi variabel bebas yaitu kompetensi sumber daya manusia $\left(X_{1}\right)$, implementasi sistem keuangan desa $\left(X_{2}\right)$ terhadap variabel terikat yaitu akuntabilitas pengelolaan dana desa (Y). Berdasarkan hasil SPSS yang dapat dilihat pada Tabel 5.

Tabel 5. Koefisien Determinasi $\left(R^{2}\right)$

\begin{tabular}{llllll}
\hline Model & $\mathrm{R}$ & $\mathrm{R}$ Square & Adjusted $\mathrm{R}$ Square & $\begin{array}{l}\text { Std. Error of the } \\
\text { Estimate }\end{array}$ & (20) \\
\hline 1 & $0,814^{\mathrm{a}}$ & 0,662 & 0,657 & 3,47093 & \\
\hline
\end{tabular}

Sumber: Data Penelitian, 2019

Berdasarkan Tabel 5. tersebut dapat diketahui bahwa nilai $r$ square $\left(r^{2}\right)=$ 0,662 Adapun analisis menggunakan rumus sebagai berikut:

$$
\begin{gathered}
D=r^{2} \times 100 \% \\
D=0,662 \times 100 \% \\
D=66,2 \%
\end{gathered}
$$

Berdasarkan hasil tersebut diketahui bahwa nilai $\mathrm{R}^{2}=66,2 \%$, yang berarti bahwa sebesar $66,2 \%$ akuntabilitas pengelolaan dana desa di kabupaten badung dipengaruhi oleh variabel kompetensi sumber daya manusia $\left(X_{1}\right)$, implementasi sistem keuangan desa $\left(X_{2}\right)$, dan sisanya sebesar 33,8\% dipengaruhi oleh variabel lain yang tidak diteliti pada penelitian ini.

Uji $\mathrm{F}$ atau uji kelayakan model digunakan untuk mengetahui apakah seluruh variabel bebas (kompetensi sumber daya manusia dan implementasi sistem keuangan desa) memiliki pengaruh secara simultan terhadap variabel terikat (akuntabilitas engelolaan dana desa). Tabel 6. menunjukkan hasil perhitungan uji $\mathrm{F}$ dengan menggunakan SPSS 21.

Tabel 6. Hasil Uji F

\begin{tabular}{lllllll}
\hline Model & & Sum of Squares & $\mathrm{df}$ & Mean Square & $\mathrm{F}$ & Sig. \\
\hline \multirow{3}{*}{1} & Regression & 2908,713 & 2 & 1454,357 & 120,720 & $0,000^{\mathrm{b}}$ \\
& Residual & 1481,823 & 123 & 12,047 & & \\
& Total & 4390,537 & 125 & & & \\
\hline
\end{tabular}

Sumber: Data Penelitian, 2019

Statistik Uji F Berdasarkan hasil perhitungan menggunakan program Statistical Package for Social Science (SPSS) version 21 for windows, pada tabel ANOVA diketahui $F_{\text {sig }}$ sebesar 0,000 (lampiran 6). Kesimpulan Berdasarkan hasil analisis, diketahui nilai signifikansi $\mathrm{F}$ adalah 0,000 $<0,05$, maka $\mathrm{H}_{0}$ ditolak. Hal ini berarti bahwa variabel kompetensi sumber daya manusia $\left(\mathrm{X}_{1}\right)$, variabel implementasi sistem keuangan desa $\left(\mathrm{X}_{2}\right)$, secara simultan berpengaruh signifikan terhadap akuntabilitas pengelolaan dana desa $(Y)$ di Kabupaten Badung, atau model yang digunakan dalam penelitian layak dan dapat dipergunakan untuk analisis berikutnya.

Berdasarkan pengolahan data SPSS dihasilkan tingkat signifikansi 0,000< 0,05 dengan koefisiennya sebesar 0,509. Berdasarkan nilai pengujian tersebut, 
dapat dilihat bahwa uji jatuh pada penolakan $\mathrm{H}_{0}$ ditolak dan $\mathrm{H}_{1}$ diterima untuk hipotesis pertama. Hal tersebut menyatakan bahwa terdapat pengaruh positif dan signifikan antara kompetensi sumber daya manusia terhadap akuntabilitas pengelolaan dana desa di Kabupaten Badung. Apabila kompetensi sumber daya manusia meningkat maka akuntabilitas pengelolaan dana desa akan meningkat sebesar 0,509. Dalam pengelolaan dana desa, pemerintah desa harus memiliki kompetensi sumber daya manusia yang berkualitas yang dapat dilihat dari latar belakang pendidikan, pengalaman mengikuti pelatihan, mengerti tentang akuntansi dan dana desa serta memahami peraturan dan prosedur mengenai pengelolaan dana desa beserta tujuan dana tersebut diberikan oleh pemerintah.

Hasil ini sesuai dengan stewardship theory yang menjelaskan pemerintah desa bertindak sebagai stewards yang menerima tanggung jawab untuk mengelolaan dana desa yang dikucurkan oleh pemerintah pusat untuk kepentingan desa. Sebagai stewards, maka pemerintah desa harus mengupayakan akuntabilitas pengelolaan dana desa dengan kompetensi yang mumpuni memahami tugas pokok, perencanaan dan penganggaran keuangan desa serta mampu menyusun laporan keuangan desa serta mematuhi norma aturan- aturan yang berlaku dan didukung dengan pengetahuan, kemampuan, pelatihan, keterampilan dan kerjasama. Kompetensi sumber daya manusia yang pada penelitian ini adalah aparatur desa yang baik maka semakin tinggi akuntabilitas dalam pengelolaan dana desa. Hasil penelitian ini sesuai dengan penelitian yang dilakukan oleh Dewi \& Gayatri (2019) dan Makalalag (2017) menyatakan bahwa kompetensi aparatur berpengaruh positif terhadap akuntabilitas pengelolaan dana desa.

Berdasarkan pengolahan data SPSS dihasilkan tingkat signifikansi 0,000< 0,05 dengan koefisiennya 0,897. Berdasarkan nilai pengujian tersebut, dapat dilihat dengan statistik bahwa uji jatuh pada penolakan $\mathrm{H}_{0}$ ditolak dan $\mathrm{H}_{1}$ diterima untuk hipotesis kedua. Hal tersebut menyatakan implementasi sistem keuangan desa berpengaruh positif dan signifikan terhadap akuntabilitas pengelolaan dana desa di Kabupaten Badung. Apabila implementasi sistem keuangan desa meningkat maka akuntabilitas pengelolaan dana desa akan meningkat sebesar 0,897. Pemanfaatan teknologi informasi dalam suatu organisasi desa akan membantu desa dalam melaksanakan tata kelola keuangan desa secara efisien.

Hasil ini sesuai dengan stewardship theory yang menjelaskan pemerintah desa bertindak sebagai stewards yang menerima tanggung jawab untuk mengelolaan dana desa yang diberikan oleh pemerintah pusat untuk kepentingan desa dengan memanfaatkan teknologi informasi, yaitu sistem keuangan desa (SISKEUDES) ini merupakan salah satu teknologi informasi yang disiapkan oleh Kemendagri bersama BPKP yang diharapkan bisa memperoleh kemudahan dan kesederhanaan dalam pengelolaan dana desa. Hasil penelitian ini sesuai dengan penelitian yang dilakukan Abdullah \& Samad (2019) menyatakan bahwa sistem keuangan desa belum berpengaruh positif terhadap penyelenggaraan pemerintahan di Desa Tokaka. Penelitian Gayatri \& Latrini (2018) menyatakan bahwa penerapan SISKEUDES efektif terhadap kualitas laporan keuangan dana desa dan penelitian Sulina, et al., (2017) juga menyatakan 
bahwa SISKEUDES berpengaruh positif terhadap kinerja pemerintah desa di Desa Kaba- Kaba.

\section{SIMPULAN}

Hasil penelitian ini menghasilkan simpulan mengenai pengaruh kompetensi sumber daya manusia dan implementasi sistem keuangan desa pada akuntabilitas pengelolaan dana desa yang dilakukan pada desa- desa di Kabupaten Badung. Hasil uji penelitian ini menemukan bahwa kompetensi sumber daya manusia dan implementasi sistem keuangan desa berpengaruh positif terhadap akuntabilitas pengelolaan dana desa. Secara teoretis penelitian ini juga memberikan pemahaman bahwa kompetensi sumber daya manusia yaitu aparatur desa dan sistem keuangan desa secara nyata dapat meningkatkan akuntabilitas dalam pengeloaan dana desa. Hasil penelitian ini dapat digunakan sebagai motivasi dan refrensi bagi pihak pemerintah desa di Kabupaten Badung untuk tetap meningkatkan kompetensi sumber daya manusianya dan pengimplementasian sistem keuangan desa semakin ditingkatkan agar tercapainya akuntabilitas dalam pengelolaan dana desa sehingga membuat masyarakat merasa tidak khawatir dan tentunya percaya terhadap pemerintahan desa di Kabupaten Badung dealam pengelolaan dana desa.

\section{REFERENSI}

Abdullah, M., \& Samad, A. (2019). Pengaruh Sistem Informasi Keuanga Desa (SISKEUDES) Terhadap Kinerja Kepala Desa (Studi Kasus Desa Tokaka, Kecamatan Gane Barat Utara, Kabupaten Halmahera Selatan ). IJIS-Indonesia Journal on Information System, 4, 69-76. https:/ / doi.org/10.1021/jp5128578

Abidin, M. Z. (2015). Tinjauan Atas Pelaksanaan Keuangan Desa Dalam Mendukung Kebijakan Dana Desa ( Study of Implementation of Village Finance to Support Fund Village Policy ). Jurnal Ekonomi \& Kebijakan Publik, $6(1), 61-76$.

Achyani, F. (2019). The Determinant Accountability of Village Funds Management ( Study in The Villages in Wonogiri District ). Riset Akuntansi Dan Keuangan Indonesia, 4(2), 118-135.

Bali, Antara. (2016). Badung dan BPKP Bali Kerja Sama Aplikasi SISKEUDES. https:/ / bali.antaranews.com/ berita/87224/ badung-dan-bpkp-bali-kerjasama- aplikasi-siskeudes. Diakses pada 10 September 2019.

Bali Express. (2018). Korupsi APBDes Mengwitani, Mantan Bendahara Divonis 2,5Tahun.https://baliexpress.jawapos.com/read/2018/03/27/60434/korup si-apbdes-mengwitani-mantan-bendahara-divonis-25-tahun. Diakses pada 10 September 2019.

Dewi, N. K. A. J. P., \& Gayatri, G. (2019). Faktor-Faktor Yang Berpengaruh Pada Akuntabilitas Pengelolaan Dana Desa. E-Jurnal Akuntansi, 26, 1269. https:// doi.org/10.24843/eja.2019.v26.i02.p16

Diansari. (2015). Analisa Implementasi Alokasi Dana Desa (Add) Kasus Seluruh Desa Di Kecamatan Kledung Kabupaten Temanggung Tahun 2013. Seminar Nasional Universitas PGRI Yogyakarta, 1-11, 412-418.

Diarespati. (2017). Pengaruh Kompetensi dan Sistem Pengendalian Internal Terhadap Akuntabilitas Pemerintah Desa dalam Pengelolaan Alokasi Dana 
Desa (ADD). Berkala Akuntansi Dan Keuangan Indonesia, 02, 1-20.

Donaldson, L., \& Davis, J. H. (1991). Stewardship Theory or Agency Theory: CEO Governance and Shareholder Returns. Australian Journal of Management, 16(1), 49-64. https://doi.org/10.1177/031289629101600103

Gayatri, G., Latrini, M. Y., \& Widhiyani, N. L. S. (2017). Transparansi dan Akuntabilitas Pengelolaan Keuangan Dana Desa untuk Mendorong Kemandirian Masyarakat Pedesaan. Jurnal Ekonomi Kuantitatif Terapan, 175182. https:// doi.org/10.24843/jekt.2017.v10.i02.p07

Gayatri, \& Latrini, M. Y. (2018). Efektivitas Penerapan SISKEUDES dan Kualitas Laporan Keuangan Dana Desa. Jurnal Imiah Akuntansi Dan Bisnis, 13(2), 113122.

Hariani, D., Purbandari, T., \& Mujilan. (2013). Dukungan Manajerial dan Budaya Organisasi untuk Menuju Efektivitas Sistem Informasi. Jurnal Riset Manajemen Dan Akuntansi, 01(02), 29-36.

Hertati, L. (2015). Competence of Human Resources, The Benefits of Information Technology on Value of Financial Reporting in Indonesia. Research Journal of Finance and Accounting, 6(8), 12-18.

Indrajaya, J. A. (2017). Pengaruh Kompetensi Aparatur Desa Dan Implementasi Undang-Undang No 6 Tahun 2014 Terhadap Pengelolaan Keuangan Dana Desa. (6), i-67.

Indralesmana, K., \& Suaryana, I. (2014). Penerapan Sistem Informasi Akuntansi Dan Kinerja Individu Pada Usaha Kecil Dan Menengah Di Nusa Penida. EJurnal Akuntansi, 7(2), 345-356.

Jannah, R., Handajani, L., \& Firmansyah, M. (2018). The Influence of Human Resources, Use of Information Technology and Public Participation to the Transparancy and Accountability of Village Financial Management. International Journal of Scientific Research and Management, 6(5), 373-385. https:// doi.org/10.18535/ijsrm/v6i5.em03

Julianto, I. P., \& Dewi, G. A. K. R. S. (2019). Pengaruh partisipasi masyarakat, penggunaan sistem keuangan desa, kompetensi pendamping desa serta komitmen pemerintah daerah terhadap keberhasilan pengelolaan dana desa. Jurnal Ilmiah Akuntansi, 4(1), 24-42.

Kabar24 Bisnis. (2018). Pertumbuhan PAD Buleleng Tertinggi di Bali. https://kabar24.bisnis.com/read/20180319/78/751811/pertumbuhan-padbuleleng-tertinggi-di-bali. Diakses pada 25 Agustus 2019.

Mahayani, N. L. A. (2017). Prosocial Behavior Dan Persepsi Akuntabilitas Pengelolaan Dana Desa Dalam Konteks Budaya Tri Hita Karana. Jurnal Ilmiah Akuntansi Dan Bisnis, 129.

Makalalag, A. J., Nangoi, G. B., \& Karamoy, H. (2017). Akuntabilitas Pengelolaan Dana Desa di Kecamatan Kotamobagu Selatan Kota Kotamobagu. Jurnal Riset Akuntansi Dan Auditing "Goodwill," 8(1), 149-158. Retrieved from https://ejournal.unsrat.ac.id/index.php/goodwill/article/view/15334

Nabizadeh, S. M., \& Omrani, S. A. (2014). Effective Factors on Accounting Information System Alignment; a Step towards Organizational Performance. International Journal of Scientific and Research Publications, 4(9), $1-5$.

Peraturan Daerah Kabupaten Badung Nomor 8 Tahun 2015 tentang Keuangan 
Desa. https://peraturan.bpk.go.id/Home/Details/86279/perda-kabbadung-no-8-tahun-2015. Diakses pada 20 Agustus 2019.

Peraturan Pemerintah Nomor 60 Tahun 2014 tentang Dana Desa Yang Bersumber Dari APBN. http:/ /www.djpk.kemenkeu.go.id/?p=496. Diakses pada 20 Agustus 2019.

R Fajri, Setyowati, E., \& Siswidiyanto. (2015). Akuntabilitas Pemerintah Desa pada Pengelolaan Alokasi Dana Desa (Studi Pada Kantor Desa Ketindan, Kecamatan Lawang, Kabupaten Malang). Jurnal Administrasi Publik (JAP), 3(7), 1099-1104.

Romney, Marshall B., dan P. J. S. (2015). Accounting Information systems, 13th ed. England: Pearson Educational Limited.

Sulina, T., Wahyuni, M. A., \& Kurniawan, P. S. (2017). Peranan Sistem Keuangan Desa (Siskeudes) Terhadap Kinerja Pemerintah Desa (Studi Kasus di Desa Kaba- Kaba, Kecamatan Kediri, Kabupaten Tabanan). Jurnal Akuntansi, 8, 112.

Tribun News. (2019). Korupsi Dana Desa Kepala Desa Baha Divonis 4,5 Tahun. https:/ / bali.tribunnews.com/2019/02/14/korupsi-dana-desa-kades-bahadivonis-45-tahun-dan-harus-kembalikan-uang-negara-rp-1-m. Diakses pada 25 Agustus 2019.

Widagdo, A. K., \& Setyorini, E. (2018). Determinants of Intention To Use Village Fund Information System. Jurnal Akuntansi Dan Keuangan Indonesia, 15(1), 36-58. https:// doi.org/10.21002/jaki.2018.03 